\title{
From the Klondike to Berlin: The Yukon in the First World War
}

\author{
Michael Gates
}

Author and Historian

\begin{abstract}
The participation of the Yukon in the First World War is a neglected part of northern history. For four years, the people of the Yukon, young and old, men and women, from all walks of life, became actively involved. A quarter of the population enlisted and fought in many of the major battles of the war; many came back as heroes, while others never came home at all. Those who remained at home were heavily committed to King and Empire. Women of the Yukon volunteered for service, raised funds for the war effort, and became socially active in such causes as prohibition and suffrage. Yukoner Joe Boyle distinguished himself in Russia during the war by financing a machine gun battery of fifty men, then volunteering to save the crown jewels and national treasury of Romania, negotiating an international treaty between Russia and Romania, and establishing a spy network. Robert Service, the Bard of the Yukon, volunteered as an ambulance driver and later penned the best-selling book of poetry of his long career. Individual acts of courage led to two men from the Yukon receiving the Victoria Cross, and many others receiving other honours. George Black, the commissioner of the Yukon, volunteered for service, bringing 250 Yukon men with him to the battlefields of France. Martha Black, his wife, accompanied him and became a mother figure to the men overseas and a Yukon goodwill ambassador. Many acts of commemoration and remembrance followed the war. This article is part of a special collection of papers originally presented at "The North and the First World War" conference, held May 2016 in Whitehorse, Yukon.
\end{abstract}

The Northern Review 44 (2017): 9-30 


\section{The Beginning}

On 4 August 1914, the people of the Yukon were drawn into the vortex of a world war that would last four long years. At the end of this period, the Yukon was a different place than it had been at the beginning.

A large group of visiting Shriners had arrived in Dawson City on 3 August 1914. The wives of seventy Shriners attended a social affair at the home of Gus Johnson the afternoon of the fourth. That evening, the three theatres in Dawson City were full to capacity. Just as the performance was ending at the Dawson Amateur Athletic Association or DAAA, a copy of the Dawson Daily News War Extra reached the patrons. With the permission of Mr. Creamer, the theatre manager, news that the British fleet had sunk six German ships was read out to the crowd. Creamer projected a slide of the King on the screen, and Mr. Carpenter, who was at the keyboard providing accompaniment to the films, struck the introductory chords to Rule Britannia and the audience rose in a body and sang "until the house shook."1 That was followed by "God Save the King." When the picture of Queen Mary was projected on the screen, the crowd sang "The Maple Leaf Forever."2

Though not yet officially stated, the community knew what this meant: that Canada was, like Britain, at war with Germany. As they filed out of the three theatres showing movies that August night, onto the twilit streets of Dawson, men and women, young and old, were abuzz with earnest discussion.

The Dawson Daily News for 30 June 1914 had carried a brief article noting the assassination of Archduke Franz Ferdinand, heir to the AustroHungarian throne. The article about the event, which had world-changing consequences, consisted of only sixty-seven words. ${ }^{3}$ For weeks after that, articles appeared in the newspapers telling of the unfolding tension in Europe. But the Yukon had seemed serenely unaware of the magnitude of the developing events. "We all had read skimpy reports of European troubles in the Dawson Daily News," said Laura Berton, "but Europe, really, seemed a planet or so away." ${ }^{4}$

Official notice of Britain's declaration of war did not reach Yukon Commissioner George Black until August 6. Black immediately wired the secretary of state that a force of volunteers would be raised in the Yukon. The following day, Black placed advertisements in the newspaper calling for volunteers. He and Dr. Alfred Thompson, the Yukon's member of 
parliament, were the first to indicate their willingness to enlist by signing their names in the volunteer ledger. ${ }^{5}$

Howard Grestock, a veteran of the Boer War, was the first Yukoner who actually volunteered. Within days of the declaration, he was aboard the steamer Dawson, heading Outside to enlist. ${ }^{6}$ Grestock ultimately became one of the Yukon's war fatalities. On 4 February 1917, he was in charge of a raiding party on the Vimy front, and did not return after completion of operations. At first reported killed in action, he was in fact wounded and captured by the Germans. He died a short time later while a prisoner of war in a Bavarian field hospital at Henin Lietard. Another man, lacking the funds to obtain transportation to Whitehorse, walked the entire distance. When he later arrived in Victoria, the recruiting office rejected him because he had flat feet. A third man snowshoed 1,000 km to Whitehorse in order to enlist. ${ }^{7}$

Men started volunteering or announcing their intentions to do so as soon as war was declared. In ones and twos they left Dawson to return to eastern Canada or England to enlist or rejoin their old units. By Christmas, sixty-five men had already left to join up.

\section{Yukon Women Support the Cause}

In the Yukon, the women immediately became involved in the war effort. Mrs. Albert E. Gooderham, president of the National Chapter of the Imperial Order Daughters of the Empire or IODE, sent a telegram to the Dr. George M. Dawson Chapter seeking donations to equip a hospital ship, and Yukon women responded by quickly raising $\$ 6,450 .{ }^{8}$ The local Daughters of Nippon contributed to this fund. Even the Indigenous people of Moosehide, and visiting hunters from the Porcupine River, contributed "generously according to their means" to fundraising in subsequent months. ${ }^{9}$

From then on, every event became a fundraising activity, from weekly teas, to socials and garden parties at the Commissioner's stately mansion. Commissioner Black and his wife Martha threw themselves into the campaign without reservation. Their spacious home became the centre of many fundraising initiatives. The different chapters of the IODE held meetings there. The ladies got together there to knit socks for the Yukon men who had gone overseas.

The IODE teas were so successful that they became a regular event in the community. The most high profile event of 1916, for example, Alexandra Rose Day, was sponsored by the Dr. George M. Dawson Chapter 
at Government House on 20 July. Charming matrons circulated on the grounds selling roses hand made by disabled children in England. Bridge was played in the drawing rooms. People circulated throughout the mainfloor rooms, smoking and talking. The rooms were filled with a profusion of cut flowers taken from the government greenhouse. Ice cream, cake, sandwiches, and coffee were served on the lawn. Others played various games, the most popular being "Swat the Kaiser" - likenesses of Kaiser Wilhelm and the crown prince were placed on hinged boards in front of a canvas backstop, and three tennis balls could be thrown at them for twenty-five cents. Winners received a fancy cigar or other gift. Meanwhile, an orchestra played on the verandah, where there was also enough room for dancing waltzes and one-steps. ${ }^{10}$

The IODE held raffles, picnics, and socials; they organized dances and special events at the theatres in Dawson. The community turned out in large numbers to support every fundraiser. Students participated at all of these; their choir sang, they gave recitals, and they posed in tableaux. The Boy Scouts collected clothing to send to displaced Belgians. The Girl Guides took drill instruction from Major Knight, who was in charge of the Mounted Police in Dawson. The ladies organized Christmas gift packages to send to their men overseas; knitting socks became a patriotic pastime, for which the Yukon volunteers were especially grateful.

The Dawson chapters of the IODE were also asked to help raise funds for the Yukon Patriotic Fund. On 21 December 1914, they handed \$6,716.45 to a meeting of the executive committee for the fund, while Whitehorse responded with another $\$ 3,000$. By Christmas, these activities, and others, had raised $\$ 22,000$ for the war effort. Today, that would amount to nearly half a million dollars. By the end of the war, the people of Dawson had raised more than $\$ 150,000$ for the patriotic cause. All of this was accomplished by a population that may have been five or six thousand.

\section{The Boyle Detachment}

By early September 1914 Klondike mining millionaire Joe Boyle set about recruiting and sponsoring a machine gun battery, comprised of fifty Yukon men. A man of vision, Boyle convinced Canadian authorities to keep his group of volunteers together to be trained as a machine gun unit. Once Sam Hughes, the Canadian minister of militia, formally accepted Joe Boyle's offer to finance a machine gun detachment, things moved quickly. Drill instruction for volunteers began immediately. A mascot was chosen-a dog named Jack. And Yukon lyrics were penned for "It's

a Long Way to Tipperary." The evening of 6 October, the community 
gathered in the Arctic Brotherhood Hall, which had been gaily decorated with bunting and flags for the occasion. Stirring speeches were made, patriotic songs were sung, and special gifts were given to the volunteers, who were seated at the front of the hall.

Three days later, the volunteers assembled at the Mounted Police barracks at the south end of Front Street. Wearing khaki trousers and matching shirts, yellow mackinaws, and stiff-brimmed hats, they marched quick-step, as they had been drilled to do, down the street with flags waving, behind a small brass band, until they reached the waiting crowd at the docks near King Street.

They boarded the steamer Lightning and lined the hand rails along the decks as the crowd waved. With three cheers and a tiger, the band struck up "God Save the King," and the feisty little river boat turned away from the wharf, churned its way upriver, and disappeared in the distance. ${ }^{11}$ The thirty-nine volunteers (eleven more would join them in Whitehorse) of the Boyle Machine Gun Detachment were off to do their patriotic duty. Similar scenes would be repeated for the duration of the war. By the end of the war, it was claimed, every officer and twenty-four of the enlisted men of the Boyle detachment were reported to have received decorations. ${ }^{12}$

The Boyle Machine Gun Detachment, which was later renamed the Yukon Battery, eventually saw action in many of the major battles of the war. They were engaged in the capture of Courcelette during the Battle of the Somme; they provided barrage support at the Battle of Vimy Ridge. The French lost 50,000 troops trying to take Vimy Ridge, and the English considered the German fortifications to be impregnable, but with careful planning and the heaviest artillery barrage of the war, the Canadians took the ridge in a few hours.

Casualties took many of the Boyle men at Vimy. Private William Hayhurst, an Englishman who had been mining in the Dawson vicinity, was wounded 8 February 1917 and died of his injuries at the No. 11 Canadian Field Ambulance. ${ }^{13}$ Today he lies buried in a cemetery five kilometres west of Souchez. Private Herbert Lawless, a Mountie who had at one time been stationed at Gold Run Creek, near Granville, was killed by shrapnel at his gun emplacement near Givenchy. ${ }^{14}$ Private Reginald Gilbert was killed by shellfire while taking the village of Fresnoy, 3 May. ${ }^{15}$ The Boyle unit was at the Battle of Passchendaele in late October 1917. They suffered no casualties in this engagement, but 30 October was the bloodiest day of battle for the Yukon volunteers, with nine men from other units being killed that awful day. 
By May 1918 the original fifty men had been whittled down to a handful, so they were integrated into another unit with men who enlisted with Commissioner George Black two years earlier. This new unit was known as the $2^{\text {nd }}$ Canadian Motor Machine Gun Brigade.

\section{The Volunteers}

The Yukon's most well-known volunteer was Robert Service, who by then was a world-famous poet living in France. Service was rejected from combat because of varicose veins, and his age, but was soon engaged as an accredited war correspondent. Eager to get as close to the action as possible, he was once arrested on suspicion of being a spy and almost shot. Service finally saw the front lines as a driver in an American volunteer ambulance corps. Published in 1916, his book Rhymes of a Red Cross Man became an instant best-seller, remaining on the bestseller lists for months.

Another volunteer was Joe Boyle. For Boyle, being a generous benefactor was not enough. The summer of 1916, Boyle left Dawson on a business trip to England. Carrying the courtesy rank of lieutenant colonel in the Canadian militia, Boyle propelled himself into the centre of things in London, more from force of will than through official authority.

In 1917, under the auspices of the American Committee of Engineers, he embarked on a mission to get the Russian train system working. British intelligence officer George Alexander Hill stated that Boyle "was a born fighter, and blessed with exceptional common sense. He is independent to revolutionary extent. Etiquette and procedure meant nothing to him, especially if a job had to be done." 16

At Tarnapol, now part of the Ukraine, he helped restore order while under German attack, for which the Russians presented him with a medal. In the winter of 1917-18, he became involved in the supply of food to starving soldiers in Romania. After that, in a series of events worthy of an action movie, he arranged for the return of the Romanian national treasury and archives, which had earlier been moved to Moscow to keep them out of German hands.

Boyle moved from one exciting drama to another. He negotiated a treaty of peace between Russia and Romania; he rescued seventy Romanian dignitaries held captive in the Ukraine and escaped with them to Romania via the Black Sea; he operated an extensive spy network. And he became intimate friends with Queen Marie of Romania and the Romanian royal family. While never formally recognized by Canada at the time for his wartime accomplishments, he was decorated by several 
other countries, receiving the Distinguished Service Order from Britain, the French Croix de Guerre, the Russian Order of St. Vladimir, and the Order of the Star of Romania. Boyle may have ruffled too many official feathers at home and was never decorated by his own country while he was alive. He was finally recognized for his accomplishments as a true Canadian hero, however; in 1984, the Historic Sites and Monuments Board of Canada unveiled a plaque in his honour near one of the monster gold dredges he had built seventy years earlier.

\section{The Home Front}

George Black was descended from United Empire Loyalist stock, and was an imperialist to the core who wanted to do his patriotic duty in aid of the Empire, but it was two years before he was permitted to enlist. On 4 January 1916, he was appointed to commissioned rank of captain in the Canadian Expeditionary Force. He organized an infantry company of volunteers, and was placed in command (Fig. 1). For him, the war was a family affair. Step-son Lyman, who was adopted by Black in October 1916, volunteered when he was still a student, aged seventeen. Brother Bill Black and step-sons Warren and Donald also did wartime service.

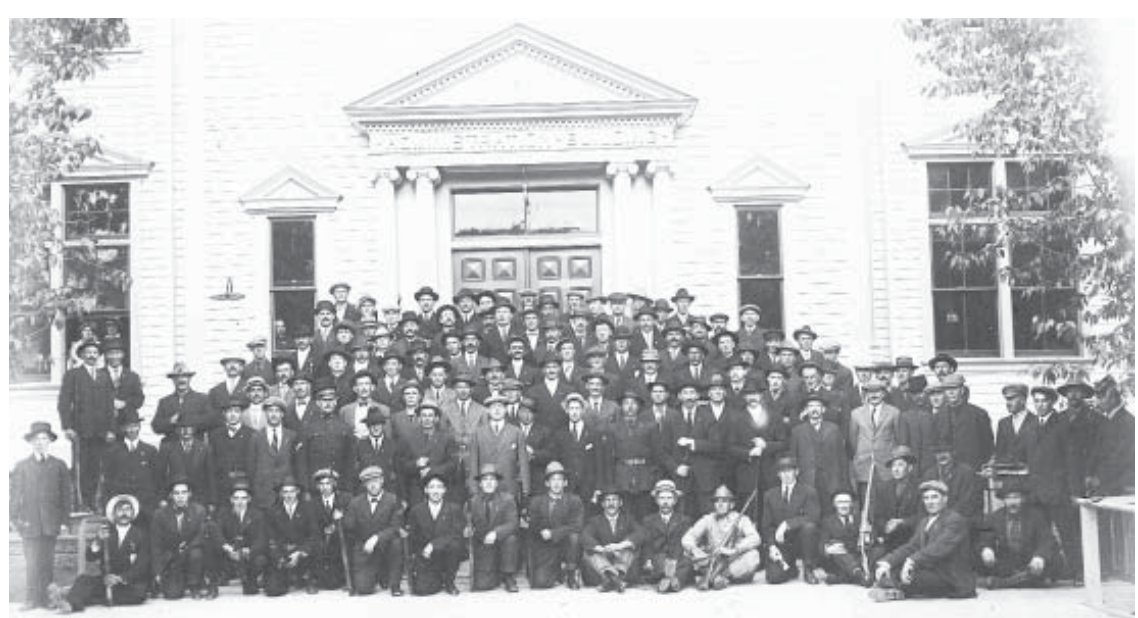

Fig. 1. The first group of men of the George Black contingent departed Dawson City in June 1916. Gates Collection 
George and Martha Black, and the last of the 275 volunteers of their contingent, marched down Front Street in Dawson City to the dock, where, with much fanfare, they boarded the Yukon River steamer Casca on 9 October 1916, and headed for Victoria.

Three months later, on 17 January 1917, the Black contingent, now the Yukon Infantry Company and 225 strong, departed Victoria where they had been stationed for training. A week later, the Blacks and the other Yukon volunteers departed Halifax for Liverpool, aboard the SS Canada. Captain Black's wife, Martha, insisted upon coming along and, after convincing the powers-that-be, she too sailed to England as the only woman of 1,500 aboard the troop ship that transported her husband and son to war.

The feelings of the Yukon men for Mrs. Black were best expressed in a rollicking impromptu shanty, sung lustily on deck every day between dashes of sea-salt spray, which showed that the one and only lady voyager was far from being an unwelcome mess mate or any damper on soldier's merriment. This is the jingle:

We have stolen Mrs. Black and we will not bring her back, 'Till the Germans quit and when the Allies win

'Till we nail the Union Jack to the Kaiser's chimney stack, 'And we toast the Yukon Daughters in Berlin. ${ }^{17}$

While stationed in London, Martha served as unofficial den mother and emissary from the Yukon. Under the auspices of the YMCA, she travelled widely in Britain, giving one, two, even three, illustrated slide talks every day. She volunteered with the Red Cross, administered the Yukon Comfort Fund, and visited wounded soldiers.

Mrs. Black wasn't the only woman to volunteer for service in Europe. Two Dawson women served as nurses during the war. Marie Thompson, daughter of Dr. W.E. Thompson of Dawson, was commissioned in the Canadian Expeditionary Force. ${ }^{18}$ Zowitza Nicholas, who had gone to school in Dawson City, travelled to Seattle where, after graduating with top honours in nursing school, she joined the American Ambulance Corps. Stationed at the Red Cross Base Hospital No. 50 at Mesves, France, she cared for sick and wounded American soldiers, many of whom died of influenza in the closing weeks of the war. "The room was so full of coffins that we had to step over them," she recalled years later. "I could never get over the terrible things that happened to those poor boys." She was later remembered as the "Angel of Ward 7."19 
The women who remained behind in Dawson City organized into a powerful agency for social change. In 1916, while George Black was organizing a contingent of Yukon volunteers to go overseas, women took on the cause of prohibition. Due to their persistent lobbying, the territorial council held a plebiscite over the issue. The vote was held 30 August 1916 and the "Wets" won by a slim margin of three votes. Women were not allowed to vote on the issue.

Aware of the implications if they had been able to cast ballots, they immediately petitioned Commissioner Black asking how they could obtain the vote. Armed with his advice, they petitioned the federal government on the matter. The timing was right. In order to advance the Borden government's wish to invoke conscription since the flow of volunteers failed to meet the demands of the war machine, some women were allowed to vote in the 1917 federal election. Within months of Borden's re-election, all women were given the right to vote. ${ }^{20}$

\section{Overseas}

Meanwhile, events were heating up for the Yukon men overseas. The Battle of Passchendaele took a terrible toll on the brave Yukon volunteers - 30 October 1917 became the bloodiest, yet most glorious day of the war for the Yukon men. Nine of them perished in battle that day. Seven were with the Princess Patricia's Canadian Light Infantry; two were with the 72nd Battalion.

Peter Allan ${ }^{21}$ was last seen at 6:00 a.m. when he left the trenches with his company. Fred La Blanche ${ }^{22}$ was killed in action in the attack west of Passchendaele. He was one of 55,000 men who were lost without trace during the defence of the Ypres Salient. Joseph Tilton ${ }^{23}$ and Peter Morrison $^{24}$ were others whose remains were never found, and whose names are memorialized at the Menin Gate in Belgium. George Otis ${ }^{25}$ with the Princess Patricia's was killed during the attack while acting as a runner. They were part of an offensive to gain a few hundred metres of sodden, crater-filled wasteland and take the village of Passchendaele from the Germans. By the time they took it, the village had been bombarded until it was nothing but rubble.

George Pearkes ${ }^{26}$ was serving in the Royal North-West Mounted Police at Whitehorse when war was declared. Before the Battle of Passchendaele, he had already been awarded the Distinguished Service Order and the Military Cross. Pearkes was with the 5th Battalion Canadian Mounted Rifles during the Battle of Passchendaele. Despite being wounded, he led 
his troops during the capture and consolidation of the line on the left flank of Passchendaele ridge, a position of critical importance to the capture of their objective. For this, he was awarded the Victoria Cross. Pearkes rose to the rank of major general by war's end, and later served as the lieutenant governor of British Columbia.

Many Yukon men had experiences in the Yukon before the war that made the combat of the trenches pale by comparison. The best example is James Murdoch Christie. Before the war, he survived a dreadful attack from a grizzly bear. In fact, his jaw had to be rebuilt by surgery so that he could once again chew his food. Forty-seven years old when he enlisted, he had to lie about his age to be accepted. He was one of the oldest Yukon enlisted men to see action on the front during the war. ${ }^{27}$

Christie rose through the ranks as he led a sniper unit in no man's land for the Princess Patricia's Canadian Light Infantry. On one trench raid, he was awarded a medal for providing covering fire, allowing the safe withdrawal of the others in his party. He became legendary for his sorties: during action on the attack of Passchendaele ridge, Christie, now an officer, was awarded the Military Cross for providing support and covering fire while two brave men from his unit attacked a seemingly impregnable pill box - and succeeded. Both men earned the Victoria Cross for their heroism. In 1918, now in his fifties, Christie was released from service and sent back to Canada. He lived another twenty years, having survived both the grizzly bear attack and nearly three years of combat in the hottest zone of the entire war.

The other recipient of the Victoria Cross claimed by the Yukon was Rowland Bourke who, after being rejected by all three branches of the Canadian armed forces for poor eyesight, returned to England where he joined the Royal Navy Volunteer Reserve. Bourke commanded a motor launch in a mission to Ostend, Belgium, rescuing men from the water while under heavy fire. His vessel was hit fifty-five times and two crewmen were killed, but many lives were saved. ${ }^{28}$

In March 1918 during the infamous German spring offensive, Lyman Black, who had been transferred to Boyle's Yukon battery, earned the Military Cross. On his own, he took over an abandoned machine gun carrier and held the line against the advancing enemy, whom he mowed down in large numbers. ${ }^{29}$

Meanwhile, in March 1918 Captain Black and his fellow Yukon volunteers were dispatched to France where they spent several months manning the line. Then, in August 1918 in the Battle of Amiens, they were sent into combat. By cover of night, the Canadian Corps, 100,000 strong, 
were secretly moved forward over congested narrow roads for the battle. Their artillery barrage opened up promptly at 4:20 a.m., 8 August 1918, with infantry and tanks following close under the barrage. The Germans were unprepared for the battle and the Allied forces, along a broad front, made the largest advances in a single day of battle since the combatants had become entrenched. George Black's battery was ready to move ahead when he was slammed in the leg by a piece of shrapnel and hit in the thigh by a machine gun round. He didn't dwell on his misfortune, but praised the efforts of his men in battle: "The Yukon boys acted just as I knew that they would. It was not their first time under fire by any means, but the first time they've gone right out in the open with no protecting trenches - set up their guns under direct enemy machine gun and artillery fire; stuck to it till they made him quit and themselves advanced as opportunity offered. The long training and thorough knowledge of machine gun tactics, coupled with their own nerve and determination, made their work all that could be desired." 30

\section{The Hundred Days}

The Battle of Amiens was the beginning of the hundred day offensive that preceded the end of the war. During this period, the Canadians and other Allied forces finally broke through the massive German trench system and pursued the enemy in open field combat. Where for years the gaining of a few yards after months of heavy battle was considered a major victory, the Allies were now advancing miles per day, making it impossible for the Germans to construct a new defensive trench system.

After Amiens, the Yukon soldiers of the $2^{\text {nd }}$ Canadian Motor Machine Gun Brigade and other units were quickly relocated north to the French city of Arras, where they formed part of the final advance into Belgium. As part of a large Canadian battle force, they fought their way through a series of German defensive lines. First, there was the Hindenburg Line, then the Fresnes-Rouvroy Line, and, last, the Drocourt-Quéant Line. Behind these defences was the unfinished Canal du Nord and, farther east, the city of Cambrai, a key transportation hub for the Germans. The ultimate target for this attack: the defensive works behind the Drocurt-Quéant Line and the town of Dury.

This was a bloody time for the Yukon. Four Yukoners fell on 2 September. Lieutenant Robert Hartman, ${ }^{31}$ of the $102^{\text {nd }}$ Battalion, was in charge of two Stokes trench mortars during an attack made on the enemy's position east of Dury. Sergeant John J. Melville, ${ }^{32}$ formerly of Atlin, British Columbia, had already been awarded the Military Medal for his bravery, but on this 
day he was killed during the attack southwest of Dury. Alfred Clinton Totty, ${ }^{33}$ son of an Anglican missionary and Indigenous mother, was with the 78th Battalion of the Canadian Infantry during the attack of the Drocourt-Quéant switch when he was killed by a machine gun bullet to the throat, 2 September. ${ }^{34}$ Alfred, his brother Elliott, and Kenneth and Hugh McDonald, are the only Yukon soldiers known to have been of Indigenous ancestry.

Saletto Michunovich ${ }^{35}$ was a miner from the Yukon. Born in Montenegro, he volunteered as a member of the George Black contingent and was later transferred to the $1^{\text {st }}$ Canadian Motor Machine Gun Brigade. While acting as a gunner on armoured car No. 5792 he was killed when it was hit by a shell. James Bow Watters ${ }^{36}$ from Atlin fell on 26 September. Marshall Stevens, Alfred Cronin, and Patrick John Martin were killed on 27 September, ${ }^{37}$ while George Crisfield and C.J.T. Stewart died the following day. ${ }^{38}$ Frank Slavin Jr. was lost on 29 September, while George Davidson was killed 3 October. ${ }^{39}$ Robert Morton, who was killed by an exploding shell, was the last Yukoner to die in battle in the military endgame, just three weeks before the Armistice was declared. ${ }^{40}$

The $2^{\text {nd }}$ Motor Machine Gun Brigade moved inexorably east toward Belgium. They were sent to Naves, then Denain and Valenciennes where the Germans were putting up a stubborn resistance; it took three days for the latter place to fall. "We entered the town with bands playing," reported one letter to Dawson. "The town was decorated with flags that had been concealed since 1914. From Valenciennes we had no heavy fighting except rear-guard actions which the Huns were putting up to enable them to get their heavy guns back." ${ }^{41}$

Somewhere between Valenciennes and Mons, on 7 November, they entered Belgium, where they were met by ecstatic citizens: "We were chasing Fritzies through a lot of French towns and villages," wrote Alfred Townsend. "Fritz was going pretty fast so he did not have much time to destroy the houses or put up much of a fight, so we got along with very few casualties." ${ }^{42}$ All the girls and women ran out and kissed and hugged the soldiers.

Alfred's brother Norton expanded upon this theme: "A good bit of the time we were just a few hundred yards behind the Germans and under fire at that. The people came out of their cellars-cheered, danced, cried and sang all at once. Old women and girls cried and kissed and hugged one till you didn't know if you were yourself or not. They cut all the badges and buttons off our clothes - stripped us of everything for souvenirs. The cruelties they suffered under the Germans are unbelievable." 43 
The Yukoners of the $2^{\text {nd }}$ Canadian Motor Machine Gun Brigade encountered sporadic fighting with the Germans as they entered Mons at 9 a.m. on 11 November, but nobody in the unit was killed that day. At 11 a.m., the Armistice began and the guns fell silent. As the Canadians made their way through Mons, the Highlanders marched their pipe band through the narrow streets, and citizens of Mons cheered. Lieutenant Lyman Black, who had left high school in Dawson City two years before to enlist, was now a battle scarred veteran of the war; he led the machine gun contingent on his motorcycle, through the city square in the centre of Mons (Fig. 2).

The response to the end of combat was greeted with celebration in the Yukon. When news reached Whitehorse and Dawson, there was much joyful exuberance. "J.B. Watson, Dominion telegraph operator, mounted to the cupola of the post office and played several coronet solos, among the selections being 'O, Canada,' 'Rule Britannia,' and 'God Save the King.' In the front window of the dry goods department of Taylor, Drury, Pedlar \& Co, a life size effigy of the bust of the Kaiser, the artistic handiwork of Charles Atherton, head of the grocery department ... was displayed." ${ }^{44}$

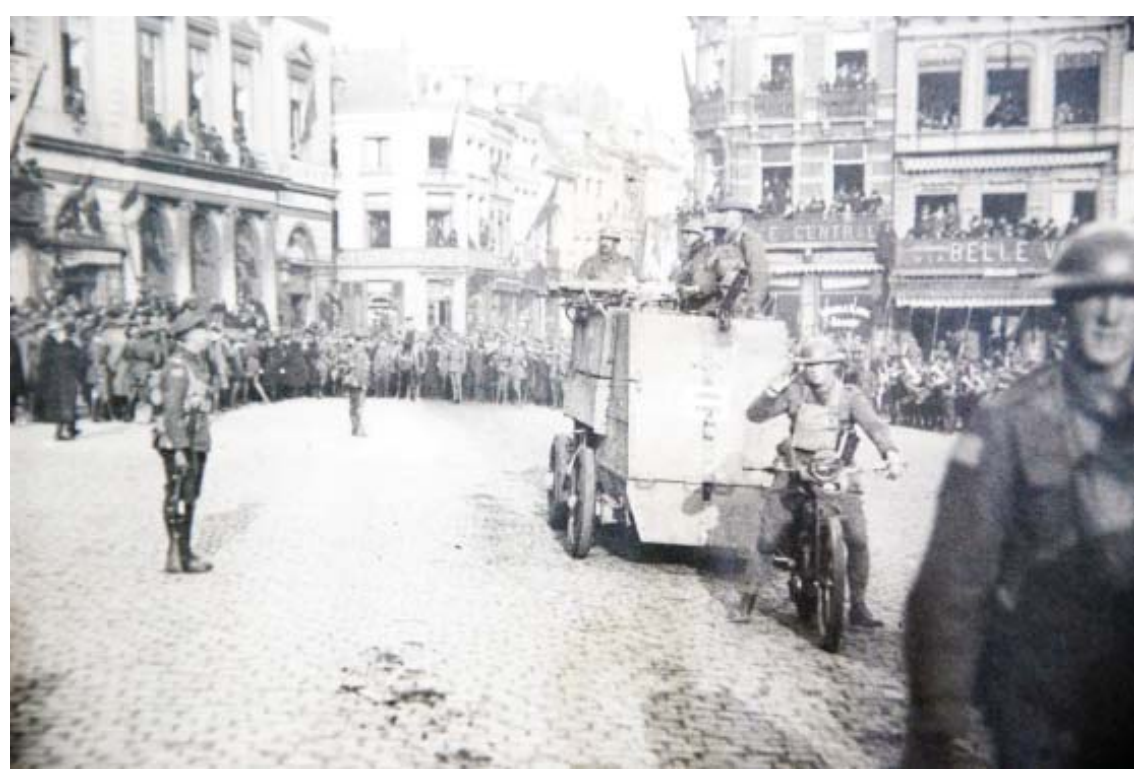

Fig. 2. Young Lyman Black (on motorcycle) was selected to lead the machine gun brigade through Mons, Belgium, at the end of the war. Yukon Archives, George Black fonds 81/107 \#197 
Forty-three Skagway and Carcross residents arrived in Whitehorse on the train the following afternoon at 4:30. Everybody in Whitehorse was there to greet them amid blowing whistles, ringing bells, and a brass band. A fine dinner followed at the Whitehorse mess house, and at seven in the evening the effigy of the Kaiser was carried up the street in a torchlight parade from the Taylor, Drury \& Pedlar store, and placed atop an eightmetre-high pile of cord wood, which was set afire in the ball field.

Dawson also went wild in celebration. The word was out at 9:40 a.m., and church bells started ringing; everywhere, whistles were blown, guns were fired, and every other sort of noisemaker was brought into action. School was let out and children poured out into the streets. They marched about town setting off firecrackers for hours. Everywhere homes were festooned with streamers and flags.

In the afternoon, returned soldiers and others formed a parade, several blocks long, headed by Sheriff Brimston. Then came returned soldiers carrying a coffin containing an effigy of the Kaiser, followed by a long line of "women representing all the patriotic societies of the town." 45 They were followed in turn by blocks of gaily adorned automobiles, then others carrying large British and American flags.

The parade led to the Arctic Brotherhood Hall where, in a crowded informal meeting chaired by Sheriff Brimston, returned veterans or relatives of war veterans were asked to take the platform; speeches were given by Colonel Knight, the acting chief executive, and by Judge John Black and other dignitaries.

\section{The Fallen}

The joy was not universal: after all, many would not be returning home. Harry McLennan ${ }^{46}$ and Cecil Mack Merritt ${ }^{47}$ were the first Yukoners to die in service; both were killed at the Battle of Ypres. Charlie Phillips from Dawson died a few months later in the East African campaign. ${ }^{48}$ George Chapman was the son of the man who ran the steam power generating plant, and Alfred Cronin worked as a clerk for the Northern Commercial store in Whitehorse. ${ }^{49}$ Jack Taylor was the son of the magistrate in Whitehorse..$^{50}$ Anthony Blaikie won both the Military Medal and the Distinguished Conduct Medal, but neither was sufficient to secure his life. He died beside Lyman Black and today lies buried in a British cemetery near Somme. ${ }^{51}$ Angus McKellar and Charlie O'Brien were both killed instantly when a shell hit their armoured car only three months before the end of the war. ${ }^{52}$ Angus was one of the first mounted policemen to 
come into the Yukon in 1895. Charlie O'Brien was the son of T.W. O'Brien, the Klondike brewery king. Charlie had just graduated from high school when he joined the George Black contingent.

These are but a few of the Yukoners who died during the war. They were enlisted men and officers; young and old. Nearly a hundred in all, they are buried in France, Belgium, and other places, taken from us in battles like those of Passchendaele, the Somme, and Amiens. We remember them by their name, rank, date of birth, and place of death. They had families back home; some had children who would never see their father again.

During the four years of conflict, more than 900 men from the territory enlisted, which was a per capita rate far higher than that of the rest of Canada. Yukon residents were proud to claim that they donated more to the war effort financially than those of any other part of the country. Had the rest of the nation responded with the same magnanimity, the public contribution to the war chest would have been ten times what it was.

As the injured and disabled veterans started to trickle back into the Yukon in the spring of 1918, they formed a group known as "The Returned Soldiers' Club." Dr. Alfred Thompson, the Yukon member of parliament, loaned space for their headquarters in a building he owned at the corner of Queen Street and Second Avenue in Dawson City. By the fall of 1918, there were a dozen members, but anticipating a large influx of returning veterans after the end of the war, on 18 October 1918, they reorganized themselves into a branch of the Great War Veterans' Association (GWVA), which eventually received its charter 29 April 1919, and secured larger quarters in a building at the corner of Duke Street and Third Avenue. To prepare for their returning comrades, the veterans turned to the ladies of Dawson, who formed the GWVA Ladies' Auxiliary. Within eight months, the ladies had raised $\$ 1,500$ for the organization; among its functions were the care of the sick and disabled, securing adequate pensions, helping find employment for returnees, and providing support for dependant families.

Almost a hundred veterans returned to the Yukon by August; eightytwo to the Dawson area, and sixteen to Whitehorse. A special reception was held for the returned veterans in the Arctic Brotherhood Hall on 11 August 1919, at which speeches were made followed by musical recitals and dancing; but, either embittered by the taste of war or eager to return to their pre-war occupation of mining, only two dozen of them attended the event.

The Yukon changed profoundly because of the war. From a high point in 1901, the population declined from 27,229 to 8,512 a decade later. By 
the end of the war, it had been halved again to 4,157 in 1921. Of the nearly 1,000 men and women who volunteered for military service, barely more than 100 of them returned to the Yukon after the Armistice. The goldfields that had produced over a million ounces of gold in 1900 produced only 85,000 ounces eighteen years later. The federal government had slashed its territorial budget from $\$ 286,436$ to $\$ 185,000$, and reduced its workforce in the Yukon from twenty-two to nine. Though it never happened in the end, Ottawa was prepared to abolish representative government in the diminished territory.

A final blow to the gold rush era came on 23 October 1918 as the end of the war approached. The steamship Princess Sophia, which sailed from Skagway, Alaska filled to capacity with passengers leaving the North for the winter, hit Vanderbilt Reef in the Lynn Canal during a violent storm. A few hours later, the ship slid off the reef and went to the bottom, taking nearly 300 Yukoners down with her. Many of the dead were prominent members of the business community; neither the population nor the economy recovered for more than two decades.

\section{Remembering}

The memorialization of the war began even before it was over. On 15 November 1918, the Yukon chapter of the IODE in Whitehorse had a temporary memorial cross prepared as a tribute to those who had "made the supreme sacrifice." As the immediacy of the war receded with time, various organizations resolved to preserve the memory of those who served and, more particularly, of those who died in service during the war. On Discovery Day 1919 the Dawson City Fraternal Order of Eagles Lodge Aerie Number 50 unveiled a monument honouring six members who gave their lives during the war.

A memorial to the fallen of the war, which was designed by mining recorder and war veteran Frank Berton, was unveiled in Whitehorse beside the public library on 9 June 1920. Berton read out the roll of the hundred names. "When the name of a dead hero was called no reply came except a tap on the muffled drum.." ${ }^{53}$ By the end of the summer, two large war trophies, a howitzer and a trench mortar, had been delivered to Whitehorse and were also placed on display by the library. Two similar pieces of German artillery, more trophies of the war, were delivered to Dawson City.

Later that year, on 11 November, a small plaque was unveiled in the Dawson City public school by Gold Commissioner Mackenzie. Upon it 
were engraved eight names of students from both Dawson schools who were killed during the war. Mackenzie noted three more. On 17 September of the following year, another plaque was unveiled in the flag-draped lobby of the Canadian Bank of Commerce in Dawson, honouring three employees of the Bank who enlisted in the war effort: John I. Miller, Frank $\mathrm{H}$. Thompson, and Albert Edward Browne. Browne was killed in action north of Neuville-Vitasse in April 1918. ${ }^{54}$

By November 1922 a memorial had been placed on the wall in the Dawson post office, in the form of a triptych, containing the names of hundreds of Yukon volunteers. The dead were denoted with a cross beside their name. The Great War Veterans' Association had long been preoccupied with re-establishing returned soldiers into civilian life, but by January 1923 they began a fundraising campaign by private subscription and raised $\$ 2,700$ for the fabrication of a war memorial. This, too, was designed by Frank Berton, who by this time had been transferred back to Dawson City.

The seven metre high granite obelisk, which was mounted on a granite base, was unveiled on a cool windy day in September 1924. Attached to its base was a plaque with the names of seventy-one dead, men whose names had been compiled locally by Arthur Coldrick and then verified in Ottawa. The obelisk was draped with two large Union Jacks, and guarded by four returned soldiers standing at the four corners. At 3:30, 150 school children arrived at the memorial and took their place on the east and south sides of the shrine. Martha Black, carrying the standard of the national body of the IODE, accompanied by Miss A. Vale with the flag, and Vice-Regent Mrs. A. McCarter, assumed a position north of the monument.

The colours of the $2^{\text {nd }}$ Motor Machine Gun Brigade were then carried in by Lieutenant Phil Creamer and Lieutenant F.G. Berton, escorted by the Royal Canadian Mounted Police (RCMP). The colours were positioned on either side of the monument, while the RCMP and veterans stood facing the memorial on the west side. The school children sang "O Canada," accompanied by John Dines, Claude Tidd, and W.F. MacKenzie.

Gold Commissioner Mackenzie gave a short speech explaining the history of the project, and thanked the public for their contributions to the memorial fund. George Black, now the territory's member of parliament, then gave a stirring speech about the men who gave their lives during the war. And with that, the memorialization of the war dead had been fulfilled. ${ }^{55}$

In the years that followed, the veterans who returned to the Yukon put their shattered lives back together and picked up where they left off before 
the war. As the years passed, they grew old, and one by one they died until the last was gone, leaving only the memories of the proud young men who had so willingly volunteered years before.

\section{The Impact}

The Yukon had been transformed dramatically by the First World War. Before the war, the aura of the gold rush still illuminated the territory and filled many with optimism and hope. The war accelerated the inexorable decline that had been going on for years. Nearly $20 \%$ of the territory's population volunteered for service to their country; only a fraction of them returned after the war. The territory they returned to was an empty husk, full of dreams and memories.

Even the federal government had abandoned the territory, reducing its workforce as well as its funding. The sinking of the Sophia near war's end seemed to knock the wind out of any optimism the Armistice might have offered. The volunteers from the Yukon who responded to the call of duty were a drop in the ocean of the Canadians who served in the expeditionary force during the war-although it was said that the Yukon gave its men and its money, its heart and its soul, to the Imperial cause in greater proportion than anywhere else in the country.

This northern refuge in the farthest reaches of the Dominion was practically forgotten. It became a sleepy backwater ignored in large part by the rest of the nation for two decades until another world war would change that and shape its destiny for the last half of the twentieth century.

\section{Author}

Michael Gates is an independent historian and author living in Whitehorse; he is the author of From the Klondike to Berlin, about the Yukon in the First World War (Harbour Publishing, April 2017).

\section{Notes}

1. "Dawson Stirred by the News of the War," Dawson Daily News (DDN), 4 Aug 1914, 4.

2. Ibid.

3. "Heir to Throne of Austria-Hungary is Assassinated," DDN, 30 Jun 1914, 1

4. Laura Berton, I Married the Klondike (McClelland and Stewart, Toronto, 1967), 128.

5. “Roll Opened in Dawson for Service," DDN, 7 Aug 1914, 4.

6. "First Yukoners Get Away for War in Europe," DDN, 7 Aug 1914, 4. 
7. DDN 29 May 1916, 1; WS 7 Apr 1916. Another prospector, Walter Scarth, was on a two-year trapping and prospecting trip on a remote tributary of the Yukon River when he received word of the war. He travelled 850 miles in an open boat to Nome to catch a ship for Seattle. He took the train to Calgary, where he enlisted in the C.E.F. Birmingham [England] Daily Gazette, 18 Sep 1915, 8.

8. “Dawson's Fund for Ship Is Nearly \$6,500," DDN 3 Sep 1914, 4.

9. "Yukon Indians Give in Aid of the Empire," DDN 23 Dec 1914, 1.

10. "Large Sum is Netted for Patriotism," DDN 21 Jul 1916, 4.

11. "Yukon's Boys Get Away for the Great War," DDN 12 Oct 1914, 4.

12. Laura Berton, I Married the Klondike, 130.

13. “Wm. Hayhurst, Klondiker, is Dead at Front,” DDN 19 Apr 1917, 4; "Canadian Virtual War Memorial, William Hayhurst," Veterans Affairs Canada, http://www.veterans.gc.ca/eng/remembrance/memorials/ canadian-virtual-war-memorial/detail/59754?William\%20Hayhurst

14. "Great Work by Yukoners at Vimy Ridge," DDN 14 Jun 1917, 4; also, "Canadian Virtual War Memorial, Herbert Maxwell Lawless," Veterans Affairs Canada, http://www.veterans.gc.ca/eng/remembrance/memorials/ canadian-virtual-war-memorial/detail/586367?Herbert $\% 20$ Maxwell $\% 20$ Lawless

15. Circumstances of Death Registers for Gilbert: Library and Archives Canada http://www.collectionscanada.gc.ca/microform-digitization/006003119.01-e.php?PHPSESSID=028f5r8mogpo7mf2v8hjq5qmo2\&sqn=56\&q2=28 $\& \mathrm{q} 3=2293 \& \mathrm{tt}=807$

16. Leonard Taylor, The Sourdough and the Queen (Methuen, Toronto, 1983), 205; Anne Merrill, “Yukon M.P.'s Wife Real 'Sour-Dough,'” Maclean's, 1 May 1922, 64; George Hill, Go Spy the Land (London: Biteback Publishing Ltd., 2014), 89.

17. Martha Black, My Seventy Years (Toronto: Thomas Nelson and Sons, 1928), 235.

18. “Thompson, Marie Louise, Soldiers of the First World War 1914-1918," Library and Archives Canada, http://www.bac-lac.gc.ca/eng/discover/ military-heritage/first-world-war/first-world-war-1914-1918-cef/Pages/ item.aspx?IdNumber $=265030$

19. “WWI Soldier Finds 'Angel'," Daily Sitka Sentinel, 12 Nov 1982, 14.

20. "Women got the federal vote in three stages: the Military Voters Act of 1917 allowed nurses and women in the armed services to vote; the Wartime Election Act extended the vote to women who had husbands, sons, or fathers serving overseas; and all women over 21 were allowed to vote as of January 1, 1919." From “Women Get The Vote 1916-1919," http://www.canadahistoryproject.ca/1914/1914-08-women-vote.html

21. "Circumstances of Death Registers, First World War: Peter Allan," Library and Archives Canada, http://www.collectionscanada.gc.ca/microform- 
digitization/006003-119.01-e.php?PHPSESSID=028f5r8mogpo7mf2v8hjq5q $\underline{\mathrm{mo}} \& \mathrm{sqn}=168 \& \mathrm{q} 2=28 \& \mathrm{q} 3=2256 \& \mathrm{tt}=597$

22. "Circumstances of Death Registers, First World War: Fred LaBlanche," Library and Archives Canada, http://www.collectionscanada.gc.ca/ microform-digitization/006003-119.01-e.php?PHPSESSID=028f5r8mogpo7 $\underline{\mathrm{mf} 2 \mathrm{v} 8 \mathrm{hjq} 5 \mathrm{qmo} \text { \&sqn }=034 \& \mathrm{q} 2=28 \& \mathrm{q} 3=2313 \& \mathrm{tt}=1039}$

23. “Canadian Virtual War Memorial, Joseph Tilton," Veterans Affairs Canada, http://www.veterans.gc.ca/eng/remembrance/memorials/ canadian-virtual-war-memorial/detail/1596635?Joseph\%20Tilton

24. "Circumstances of Death Registers, First World War: Peter Morrison," Library and Archives Canada, http://www.collectionscanada.gc.ca/ microform-digitization/006003-119.01-e.php?PHPSESSID=028f5r8mogpo7 mf2v8hjq5qmo2\&sqn $=696 \& q 2=28 \& q 3=2325 \& t t=977$

25. "Circumstances of Death Registers, First World War: George Eric Otis," Library and Archives Canada, http://www.collectionscanada.gc.ca/ microform-digitization/006003-119.01-e.php?PHPSESSID=028f5r8mogpo7 $\underline{\mathrm{mf} 2 \mathrm{v} 8 \mathrm{hjq} 5 \mathrm{qmo} 2 \& \mathrm{sqn}=1008 \& \mathrm{q} 2=28 \& \mathrm{q} 3=2336 \& \mathrm{tt}=1205}$

26. "Personnel Records Centre, George Randoph Pearkes," http://central.baclac.gc.ca/.item/?op=pdf\&app=CEF\&id=7681-35

27. Laura Berton, I Married the Klondike, 89-92; “Personnel Records Centre, James Murdock Christie, http://central.bac-lac.gc.ca/. item/?op $=$ pdf\&app=CEF\&id=B1701-S035

28. "Canadian Victoria Cross Recipients, Rowland Bourke," last modified 23 Oct 2014, Veterans Affairs Canada, http://www.veterans. gc.ca/eng/remembrance/medals-decorations/orders-decorations/ canadian-victoria-cross-recipients/bourke

29. "Supplement to the London Gazette," 23 Jul 1918, https://www.thegazette. co.uk/London/issue/30813/supplement/8860

30. George Black, "Great Fight Made by the Yukon Boys," Gold Stripe, Vol 1, Wednesday, Dec 25, 1919

31. "Ross Hartman of Dawson is Killed," DDN 9 Nov 1918, 04; "Circumstances of Death Registers, First World War: Ross Hartman," Library and Archives Canada, http://www.collectionscanada.gc.ca/ microform-digitization/006003-119.01-e.php?PHPSESSID=028f5r8mogpo7 mf2v8hjq5qmo2\&sqn $=152 \& q 2=28 \& q 3=2300 \& t t=971$

32. "Circumstances of Death Registers, First World War: John Melville," Library and Archives Canada, http://www.collectionscanada.gc.ca/ microform-digitization/006003-119.01-e.php?PHPSESSID=028f5r8mogpo7 mf2v8hjq5qmo2\&sqn=216\&q2=28\&q3=2322\&tt=799

33. “Commonwealth War Graves Registers, First World War: A.C. Totty, Library and Archives Canada, http://www.collectionscanada.gc.ca/ microform-digitization/006003-119.01-e.php?PHPSESSID=71rdeqda39td86 27p1i5ujsdc5\&sqn=320\&q2=27\&q3=2239\&tt=1089 
34. Ibid.

35. "Circumstances of Death Registers, First World War: Salette Michunovich," Library and Archives Canada, http://www.collectionscanada.gc.ca/ microform-digitization/006003-119.01-e.php?PHPSESSID=028f5r8mogpo7 $\underline{\mathrm{mf} 2 \mathrm{v} 8 \mathrm{hjq} 5 \mathrm{qmo} 2 \& \mathrm{sqn}=634 \& \mathrm{q} 2=28 \& \mathrm{q} 3=2322 \& \mathrm{tt}=799}$

36. http://data2.collectionscanada.gc.ca/microform/data2/dm13/ d13/006003/31830_B016651/jpg/31830_B016651-00812.jpg

37. http://www.collectionscanada.gc.ca/microform-digitization/006003119.01-e.php?PHPSESSID=91gjhf6kj9a0gh1n6c4d8mnml4\&sqn=88\&q2 $=27 \& q 3=2235 \& \mathrm{tt}=1139 ;$ http://www.collectionscanada.gc.ca/microformdigitization/006003-119.01-e.php?PHPSESSID=028f5r8mogpo7mf2v8hjq5 qmo2\&sqn $=656 \& q 2=28 \& q 3=2278 \& \mathrm{tt}=787 ;$ http://www.collectionscanada. gc.ca/microform-digitization/006003-119.01-e.php?PHPSESSID=028f5r8mo gpo7mf2v8hjq5qmo2\&sqn $=842 \& q 2=28 \& q 3=2320 \& t t=983$

38. http://www.collectionscanada.gc.ca/microform-digitization/006003119.01-e.php?PHPSESSID =028f5r8mogpo7mf2v8hjq5qmo2\&sqn=540\&q $\underline{2=28 \& q 3=2278 \& \mathrm{tt}=787} ; \underline{\mathrm{htt}}$ ://www.bac-lac.gc.ca/eng/discover/militaryheritage/first-world-war/first-world-war-1914-1918-cef/Pages/list.aspx?k=S urname $\% 3 a \% 22$ stewart $\% 22+$ AND+GivenName $\% 3 a \% 22$ charles+james+tow nshend $\% 22$

39. “Canadian Virtual War Memorial, FC Slavin,” Veterans Affairs Canada, http://www.veterans.gc.ca/eng/remembrance/memorials/canadianvirtual-war-memorial/detail/522438?Frank\%20Charles\%20Slavin; “Canadian Virtual War Memorial, GE Davidson," Veterans Affairs Canada, http://www.veterans.gc.ca/eng/remembrance/memorials/ canadian-virtual-war-memorial/detail/380650?George \%20Edwin $\% 20$ Davidson

40. “Canadian Virtual War Memorial, Robert Morton," Veterans Affairs Canada, http://www.veterans.gc.ca/eng/remembrance/memorials/ canadian-virtual-war-memorial/detail/399921?Robert\%20Morton

41. Letter, Norton Townsend to his mother, 15 Nov 1918. Copy in author's collection.

42. “Great Tidings from Yukon's Young Heroes," DDN, 13 Dec 1918, 4.

43. Letter, Norton Townsend to his mother, 15 Nov 1918.

44. "Celebrate the Ending of the World's War," Whitehorse Star, 15 Nov 1918, 1.

45. “Dawson is Jubilant in Victory," DDN 11 Nov 1918, 2.

46. “Canadian Virtual War Memorial, H McLennan," Veterans Affairs Canada, http://www.veterans.gc.ca/eng/remembrance/memorials/ canadian-virtual-war-memorial/detail/1594298?Harrington\%20McLennan

47. "Canadian Virtual War Memorial, CM Merritt," Veterans Affairs Canada, http://www.veterans.gc.ca/eng/remembrance/memorials/ canadian-virtual-war-memorial/detail/1594592?Cecil\%20Mack\%20Merritt 
48. "List of Yukoners in Scattered Units," DDN 17 Aug 1917, 30; "Phillips, Charles Walter, Casualty Details," Commonwealth War Graves Commission, http://www.cwgc.org/find-war-dead/casualty/125347/ PHILLIPS, \%20CHARLES\%20WALTER

49. "Circumstances of Death Registers, First World War: GH Catchpole," Library and Archives Canada, http://www.collectionscanada.gc.ca/ microform-digitization/006003-119.01-e.php?PHPSESSID=028f5r8mog po7mf2v8hjq5qmo2\&sqn=548\&q2=28\&q3=2273\&tt=95; "Circumstances of Death Registers, First World War: A. Cronin," Library and Archives Canada, http://www.collectionscanada.gc.ca/microformdigitization/006003-119.01-e.php?PHPSESSID=028f5r8mogpo7mf2v8hjq5q mo2\&sqn $=656 \& q 2=28 \& q 3=2278 \& t t=787$

50. “List of Yukoners in Scattered Units," DDN, 17 Aug 1917, 30;

"Canadian Virtual War Memorial, JS Taylor," Veterans Affairs Canada, http://www.veterans.gc.ca/eng/remembrance/memorials/ canadian-virtual-war-memorial/detail/1576457?John\%20Sanford\%20Taylor

51. “Deaths of Babb and Blaikie Confirmed," DDN, 22 May 1918, 2;

“Canadian Virtual War Memorial, A Blaikie," Veterans Affairs Canada, http://www.veterans.gc.ca/eng/remembrance/memorials/ canadian-virtual-war-memorial/detail/307410?Anthony\%20Blaikie

52. “Dead Lay Everywhere About Yukoners," DDN, 26 Sep 1918, 4; “Circumstances of Death Registers, First World War: CT O’Brien," Library and Archives Canada, http://www.collectionscanada.gc.ca/microformdigitization/006003-119.01-e.php?PHPSESSID=028f5r8mogpo7mf2v8h jq5qmo2\&sqn=92\&q2=28\&q3=2336\&tt=1205; "Circumstances of Death Registers, First World War: AP McKellar," Library and Archives Canada, http://www.collectionscanada.gc.ca/microform-digitization/006003119.01-e.php?PHPSESSID=028f5r8mogpo7mf2v8hjq5qmo2\&sqn=304\&q2=2 $\underline{8 \& \mathrm{q} 3=2331 \& \mathrm{t}=791}$

53. "Monuments for Yukoners Fallen in war," Whitehorse Star 10 Nov 1989, 6.

54. "Canadian Virtual War Memorial, AE Brown," Veterans Affairs Canada, http://www.veterans.gc.ca/eng/remembrance/memorials/ canadian-virtual-war-memorial/detail/285277?Albert $\% 20$ Edward $\% 20$ Brown

55. "How the Funds Were Raised for Monument," DDN, 27 Sep 1924, 2; also Yukon Archives, GOV 1667 file 33844, Yukon Memorial Committee. 